\title{
Antioxidant activity of plant extracts from Colombian flora
}

\author{
Oscar M. Mosquera, Yaned M. Correra, Jaime Niño*
}

Grupo de Biotecnología-Productos Naturales, Escuela de Tecnología Química, Universidad Tecnológica de Pereira, Pereira, Colombia

\begin{abstract}
RESUMO: "Atividade antioxidante de extrato de plantas da flora Colombiana". Neste estudo a atividade antioxidante de quarenta e seis extratos metanólicos de plantas das famílias botânicas Asteraceae, Euphorbiaceae, Melastomataceae, Rubiaceae e Solanaceae, coletadas no Parque Regional Natural Ucumarí (PRNU, Risaralda, Colômbia), foi determinada usando o ensaio de captação de radical livre de 1,1 difenil-2-picrilhidrazil (DPPH). Os extratos das plantas que mostraram a maior atividade antioxidante foram Phyllanthus sp. (54.0\%, Euphorbiaceae), seguido por duas espécies da família de Melastomataceae Tibouchina grossa (47.0\%) e Miconia lehmannii Cogn. (45.3\%) e Lycianthes radiata (Sendt.) Bitter. (41.5\%, Solanaceae). Esta é a primeira informação da atividade antioxidante destas espécies.
\end{abstract}

Unitermos: DPPH, captadoras de radical livre, Phyllanthus sp., Tibouchina grossa, Miconia lehmannii, Lycianthes radiata.

\begin{abstract}
In this study the antioxidant activity of forty-six methanol plant extracts, from the botanical families Asteraceae, Euphorbiaceae, Melastomataceae, Rubiaceae and Solanaceae, collected at the Regional Natural Park Ucumarí (RNPU, Risaralda, Colombia), were established by using the 1,1-diphenyl-2-picrylhydrazyl (DPPH) radical-scavenging assay. The plant extracts that showed the greatest antioxidant activity were Phyllanthus sp. (54.0\%, Euphorbiaceae), followed by the two species belonging to the Melastomataceae family Tibouchina grossa $(47.0 \%)$ and Miconia lehmannii Cogn. (45.3\%) and continuing with Lycianthes radiata (Sendt.) Bitter. (41.5\%, Solanaceae). This is the first report on the antioxidant activity of these Colombian species.
\end{abstract}

Keywords: DPPH, free radical-scavengers, Phyllanthus sp., Tibouchina grossa, Miconia lehmannii, Lycianthes radiate.

\section{INTRODUCTION}

Organisms are exposed over their life span to the effects of exogenous oxidizing agents from environmental pollutants, life style and to endogenous ones produced by metabolism. Chemical entities that act as oxidizing agents contain reactive oxygen species (ROS), namely superoxide anion $\left(\mathrm{O}_{2}{ }^{-}\right)$, hydroxyl ( $\left.\mathrm{HO}^{*}\right)$, and peroxyl (ROO') radicals, or reactive nitrogen species (RNS), which include agents like peroxynitrite anion $\left(\mathrm{ONOO}^{-}\right)$and nitric oxide $\left(\mathrm{NO}^{*}\right)$ radical, among other; in addition, there are non-free radical species such as hydrogen peroxide $(\mathrm{HOOH})$, nitric oxide (NO) and hypochlorous acid $(\mathrm{HClO})$ which also behave like oxidizing agents (Golden et al., 2002).

Numerous previous studies have shown that ROS and RNS agents cause lipid peroxidation, proteinprotein cross linking, oxidation of polypeptide backbones producing structural brittle proteins, DNA single-strand breaks, DNA intra-strand adducts, DNA-protein crosslinks (van Houten et al., 2006; Pelicano et al., 2004).
All these processes can cause indiscriminate alterations related to the pathogenesis of serious conditions, such as aging, atherosclerosis, cataracts, chronic inflammation; as well as, diabetes mellitus, cancers, cardiovascular disorders, liver and neurodegenerative diseases (Pelicano et al., 2004; Gonçalves et al., 2005; Kim et al., 2003; Lim and Murtijaya, 2007).

Antioxidants have been used in the food industry to prolong the shelf life of foods, specially those rich in polyunsaturated fats, due to the lipids peroxidation. As a consequence increases food deterioration, discoloration, and nutritional losses, among others. In order to stop these deterioration processes the addition of synthetic antioxidants named butylated hydroxyanisole (BHA), butylated hydroxytoluene (BHT), tertiary butylhydroquinone, and propyl-gallate has been widely used industrially. Nevertheless, the incorporation of these synthetic antioxidants in food preparations has been questioned due to their potential health risks and toxicity (Wong et al., 2006).

Some examples of plants that have been 
exhaustively studied in the few last years for their antioxidant and radical scavenging activities and that belong to the same botanical families selected for this work are: the crude extract, fractions and pure compounds from Chimarrhis turbinata (Rubiaceae) (Cardoso et al., 2005) and the crude extract of Baccharis grisebachi (Asteraceae), both species displayed strong free radical scavenging activity attributed to their flavonoid constituents (Tapia et al., 2004); in addition, the antioxidant activity from the crude extracts and fractions from Tagetes maxima and Mikania psilostachya among nine Bolivian plants belonging to the Asteraceae family were attributed to the phenolic compounds present on these two bioactive species studied (Parejo et al., 2005). Furthermore, Withania somnifera L. Dunal (Solanaceae) contains withanolides which can explain its antioxidant effects (Scartezzini and Speroni, 2000).

In addition, in a study with 32 methanolic extracts, from Brazilian Caatinga plants, which included several families studied in this work, through DPPH radical scavenging assay showed that the species Diodia apicualta $\left(\mathrm{IC}_{50}=1.3 \mathrm{mg} / \mathrm{L}\right.$, Rubiaceae) displayed good antioxidant activity, followed by Nicandra physaloides $\left(\mathrm{IC}_{50}=4.2 \mathrm{mg} / \mathrm{L}\right.$, Solanaceae $)$ and by Croton moritibensis $\left(\mathrm{IC}_{50}=5.5 \mathrm{mg} / \mathrm{L}\right.$, Euphorbiaceae) (David et al., 2007).

The fact that tropical plants produce high levels of antioxidant compounds to tolerate ultraviolet radiation, the beneficial and protecting effects of these compounds in health and diseases management, and the needs of diminishing the incorporation of synthetic antioxidants to promote the use of natural ones in commercial food and cosmetic preparations, prompted us to search 46 methanol plant extracts from five botanical families collected at Regional Natural Park Ucumarí (RNPU, Colombia) for their antioxidant activity.

\section{MATERIAL AND METHODS}

The solvent hexane, dichloromethane and methanol (analytical grade) were purchased from Mallinckrodt (Phillipsburg, NJ, USA), 1,1-diphenyl2-picrylhydrazyl (DPPH) and hydroquinone were obtained from Sigma (St. Louis, MO, USA). Silica gel plates (60 F254 $0.2 \mathrm{~mm}$ ) were purchased from Merck (Darmstadt, Germany). A Spectronic Genesys 5 UVVIS spectrophotometer Milton Roy (Rochester, NY, USA) was used for all determinations.

\section{Plant collection and extract preparation}

Plants from the selected families were collected at random at different zones from the Regional Natural Park Ucumarí (RNPU) located in Risaralda, Colombia. It has an extension of 4,240 hectares, and it is located on the west flank of the Andean Central Mountain Chain, it is constituted by a high percentage of secondary forests; it has an average temperature of $15^{\circ} \mathrm{C}$ and a pluvial precipitation of 2,780 $\mathrm{mm} /$ year and an altitudinal range from 1,850 to 2,650 meters above sea level (Galeano and Bernal, 1993).

Plants were collected on February 2000 and
October 2001 and were classified by Dr F. J. Roldán and are listed in Table 1. A voucher specimen for each plant was deposited at the University of Antioquia Herbarium (Medellín, Colombia).

The aerial plant materials were oven-dried at $50{ }^{\circ} \mathrm{C}$, ground and extracted by $48-\mathrm{h}$ maceration three times successively with the following solvents: hexane, dichloromethane and methanol, all at room temperature. Then, the different extracts were concentrated at reduced pressure to dryness and stored at $-10{ }^{\circ} \mathrm{C}$ until assayed (Niño et al., 2006).

\section{Phytochemical analysis}

For each methanol plant extract a phytochemical screening was performed testing the presence of secondary metabolites by using TLC. For the TLC analysis of the methanol extracts the solvent system chloroform-ethyl acetate-methanol (2:2:1) was used. After the development in the solvent system the plates were dried and sprayed with: Dragendorff's, anisaldehyde-sulphuric acid, $1 \%$ vanillin in sulphuric acid-ethanol, $1 \%$ ferric chloride, $2 \%$ aluminium chloride in ethanol and hydroxylamine-ferric chloride for detection of alkaloids, sterols, saponins, tannins, flavonoids and lactones/esters, respectively (Harborne, 1980). All determinations were done in duplicate.

\section{Antioxidant activity assay for DPPH free radical scavenging activity}

The antioxidant activity of the 46 methanol extracts was evaluated spectrophotometrically following the DPPH method described by Brand-Williams et al., (1995). Each plant extract was evaluated at $100 \mathrm{mg} / \mathrm{L}$, by mixing $0.75 \mathrm{~mL}$ of them with $1.5 \mathrm{~mL}$ of a freshly prepared DPPH solution $(20 \mathrm{mg} / \mathrm{L})$; then, each particular sample was mixed thoroughly and kept in the dark for 30 minutes, at room temperature. After that, each mixture was tested for the DPPH radical-scavenging activity by reading the absorbance at $517 \mathrm{~nm}$ on a UVVIS spectrophotometer. As blank was used a solution prepared by mixing $0.75 \mathrm{~mL}$ of ultra pure water with $1.5 \mathrm{~mL}$ of the DPPH solution $(20 \mathrm{mg} / \mathrm{L})$ and reading at the same wavelength. In addition, to eliminate the absorbance of the crude extracts at this wavelength, blank samples were prepared with $0.75 \mathrm{~mL}$ of each extract and $1.5 \mathrm{~mL}$ of methanol. The antioxidant activity percentage was calculated following the formula:

Antioxidant activity $(\%)=$

[(AControl - AExtract)/AControl] x 100

Where AControl is the absorbance of a DPPH solution without extract, AExtract is the absorbance of the tested extract, which is equal to the absorbance of the plant extract plus the DPPH $(20 \mathrm{mg} / \mathrm{L})$ minus the blank extract absorbance (Ribeiro et al., 2005). As positive control hydroquinone at $100 \mathrm{mg} / \mathrm{L}$ was used. The samples were run in triplicate and the mean value of three of them was recorded. 
Table 1. Plants collected at the Regional Natural Park Ucumarí (RNPU) with their percentage of antioxidant activities and the phytochemical screening.

\begin{tabular}{|c|c|c|c|c|c|c|c|c|}
\hline \multirow{2}{*}{ Family } & \multirow{2}{*}{$\begin{array}{l}\text { Scientific names and } \\
\text { voucher number }\end{array}$} & \multirow{2}{*}{$\begin{array}{l}\text { Percentage of } \\
\text { antioxidant } \\
\text { activity }\end{array}$} & \multicolumn{6}{|c|}{ Phytocompounds $^{1}$} \\
\hline & & & Alkaloids & $\begin{array}{c}\text { Sterols, } \\
\text { triterpenes }\end{array}$ & Saponins & Tannins & Flavonoids & Lactones \\
\hline \multirow{24}{*}{ 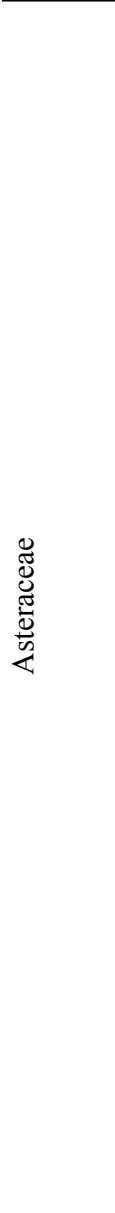 } & Ageratina & 30.1 & + & + & - & + & + & + \\
\hline & $\begin{array}{l}\text { popayanenses } \\
\text { (Hieron.) K.\& R. } \\
\text { (FJR3174) }\end{array}$ & & & & & & & \\
\hline & Aspilia quinquenervis & 26.1 & - & + & + & +++ & - & - \\
\hline & Blake (FJR3750) & & & & & & & \\
\hline & Chromolaena & 0 & - & +++ & + & + & + & - \\
\hline & tequendamensis & & & & & & & \\
\hline & (Hieron.) R.M. King & & & & & & & \\
\hline & \& H. Rob. (FJR3730) & & & & & & & \\
\hline & Liabum asclepiadeum & 0 & - & ++ & + & - & + & - \\
\hline & Sch. Bip. (FJR3720) & & & & & & & \\
\hline & Mikania leiostachya & 33.0 & + & + & - & + & + & ++ \\
\hline & Benth. (FJR3176) & & & & & & & \\
\hline & Montanoa sp. & 4.0 & - & - & - & - & - & - \\
\hline & (FJR3749) & & & & & & & \\
\hline & Munnozia & 0 & - & + & ++ & - & - & - \\
\hline & polymonioides & & & & & & & \\
\hline & (DC.) Rob. \& Bret. & & & & & & & \\
\hline & (FJR3716) & & & & & & & \\
\hline & Munnozia senecionidis & 0 & - & - & - & - & - & - \\
\hline & Benth. (FJR3721) & & & & & & & \\
\hline & Schistocarpha & 0 & - & + & - & - & - & - \\
\hline & $\begin{array}{l}\text { sinforosi Cuatrec. } \\
\text { (FJR3725) }\end{array}$ & & & & & & & \\
\hline & Verbesina nudipes & 9.0 & - & + & + & - & - & - \\
\hline & Blake (FJR3746) & & & & & & & \\
\hline \multirow{16}{*}{ 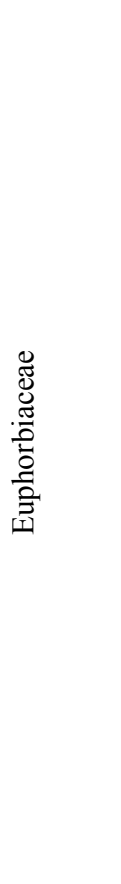 } & Acalypha diversifolia & 32.0 & - & - & +++ & +++ & - & + \\
\hline & Jacq. (FJR3726) & & & & & & & \\
\hline & Acalypha & 0 & - & - & - & - & - & - \\
\hline & $\begin{array}{l}\text { macrostachya Jacq. } \\
\text { (FJR3738) }\end{array}$ & & & & & & & \\
\hline & Alchornea glandulosa & 27.0 & - & + & +++ & - & - & + \\
\hline & Poepp. (FJR3742) & & & & & & & \\
\hline & Alchornea grandiflora & 37.0 & - & + & + & +++ & - & + \\
\hline & Müll. Arg. (FJR3727) & & & & & & & \\
\hline & Croton magdalenensis & 0 & - & + & - & - & - & - \\
\hline & Müll. Arg. (FJR3736) & & & & & & & \\
\hline & Hyeronima & 37.1 & - & + & + & + & - & - \\
\hline & macrocarpa Muell.- & & & & & & & \\
\hline & Arg (FJR3200) & & & & & & & \\
\hline & $\begin{array}{l}\text { Phyllanthus niruri L. } \\
\text { (FJR3734) }\end{array}$ & 31.8 & - & - & - & +++ & ++ & + \\
\hline & $\begin{array}{l}\text { Phyllanthus sp. } \\
\text { (FJR3715) }\end{array}$ & 54.0 & - & + & - & +++ & - & + \\
\hline & $\begin{array}{l}\text { Sapium stylare Muell.- } \\
\text { Arg. (FJR3160) }\end{array}$ & 35.0 & + & + & - & ++ & - & +++ \\
\hline
\end{tabular}




\begin{tabular}{|c|c|c|c|c|c|c|c|c|}
\hline \multirow{2}{*}{ Family } & \multirow{2}{*}{$\begin{array}{l}\text { Scientific names and } \\
\text { voucher number }\end{array}$} & \multirow{2}{*}{$\begin{array}{c}\text { Percentage of } \\
\text { antioxidant } \\
\text { activity }\end{array}$} & \multicolumn{6}{|c|}{ Phytocompounds $^{1}$} \\
\hline & & & Alkaloids & $\begin{array}{c}\text { Sterols, } \\
\text { triterpenes }\end{array}$ & Saponins & Tannins & Flavonoids & Lactones \\
\hline \multirow{8}{*}{ 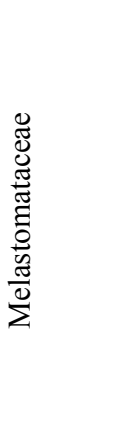 } & Miconia aeruginosa & 36.2 & - & + & + & +++ & +++ & + \\
\hline & Naudin (FJR3741) & & & & & & & \\
\hline & Miconia lehmannii & 45.3 & + & - & + & + & - & + \\
\hline & Cogn. (FJR3172) & & & & & & & \\
\hline & Miconia & 0 & - & + & +++ & - & + & - \\
\hline & $\begin{array}{l}\text { quintuplinervia Cong } \\
\text { (FJR3743) }\end{array}$ & & & & & & & \\
\hline & Miconia sp. (FJR3739) & 0 & - & + & - & - & - & - \\
\hline & $\begin{array}{l}\text { Tibouchina grossa } \\
\text { (FJR3157) }\end{array}$ & 47.0 & + & - & + & +++ & + & +++ \\
\hline \multirow{10}{*}{ 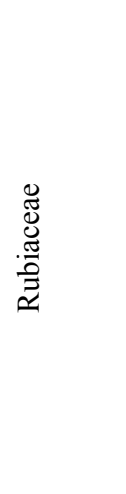 } & Cinchona pubescens & 16.4 & ++ & - & - & - & - & - \\
\hline & Vahl. (FJR3161) & & & & & & & \\
\hline & Dioicidendron dioicum & 12.1 & - & + & ++ & - & - & - \\
\hline & Steyerm. (FJR3748) & & & & & & & \\
\hline & Gonzalagunia rosea & 0 & - & ++ & ++ & + & +++ & - \\
\hline & Standl. (FJR3731) & & & & & & & \\
\hline & Hoffmannia asperula & 9.2 & ++ & - & + & ++ & - & +++ \\
\hline & Standl. (FJR3169) & & & & & & & \\
\hline & Palicourea & 36.1 & ++ & - & +++ & ++ & + & + \\
\hline & $\begin{array}{l}\text { angustifolia Kunth } \\
\text { (FJR3158) }\end{array}$ & & & & & & & \\
\hline \multirow{25}{*}{ 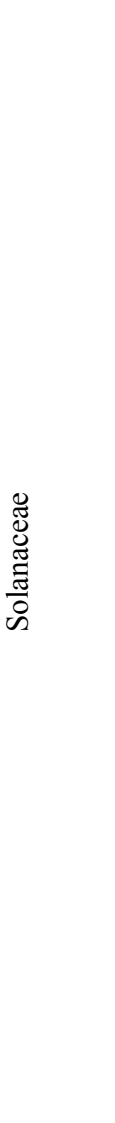 } & Browallia speciosa & 0 & - & - & - & - & - & - \\
\hline & Hook. (FJR3732) & & & & & & & \\
\hline & Cestrum ochraceum & 7.3 & +++ & - & ++ & - & - & + \\
\hline & Francey (FJR3166) & & & & & & & \\
\hline & Cestrum olivaceum & 3.6 & + & + & - & ++ & - & - \\
\hline & Francey (FJR3159) & & & & & & & \\
\hline & Deprea glabra & 0 & - & - & - & - & ++ & - \\
\hline & (Standl.) A.T. & & & & & & & \\
\hline & Hunziker (FJR3722) & & & & & & & \\
\hline & Lycianthes acutifolia & 37.7 & ++ & - & - & - & + & - \\
\hline & (R. \& P.) Bitter & & & & & & & \\
\hline & (FJR3156) & & & & & & & \\
\hline & Lycianthes radiata & 41.5 & + & - & - & - & + & - \\
\hline & (Sendt.) Bitter & & & & & & & \\
\hline & (FJR3154) & & & & & & & \\
\hline & Lycianthes $\mathrm{sp}$. & 0 & - & - & - & + & + & - \\
\hline & $($ FJR3735) & & & & & & & \\
\hline & Lycianthes synanthera & 0 & - & - & - & - & - & - \\
\hline & (Sendt.) Bitter & & & & & & & \\
\hline & (FJR3719) & & & & & & & \\
\hline & Solanum & 0 & - & - & - & - & ++ & - \\
\hline & aphyodendron $\mathrm{S}$. & & & & & & & \\
\hline & Knapp (FJR3729) & & & & & & & \\
\hline & Solanum deflexiflorum & 0 & ++ & + & - & - & + & - \\
\hline & Bitter (FJR3718) & & & & & & & \\
\hline
\end{tabular}




\begin{tabular}{|c|c|c|c|c|c|c|c|c|}
\hline \multirow{2}{*}{ Family } & \multirow{2}{*}{$\begin{array}{l}\text { Scientific names and } \\
\text { voucher number }\end{array}$} & \multirow{2}{*}{$\begin{array}{l}\text { Percentage of } \\
\text { antioxidant } \\
\text { activity }\end{array}$} & \multicolumn{6}{|c|}{ Phytocompounds $^{1}$} \\
\hline & & & Alkaloids & $\begin{array}{c}\text { Sterols, } \\
\text { triterpenes }\end{array}$ & Saponins & Tannins & Flavonoids & Lactones \\
\hline \multirow{17}{*}{ 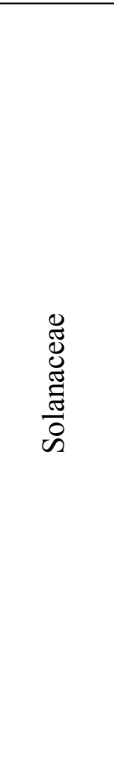 } & Solanum lepidotum & 0 & - & - & - & + & - & - \\
\hline & Dunal (FJR3728) & & & & & & & \\
\hline & Solanum leucocarpum & 1.0 & +++ & + & - & + & - & - \\
\hline & Dunal (FJR3717) & & & & & & & \\
\hline & Solanum ovalifolium & 0 & ++ & - & - & + & - & - \\
\hline & Dunal (FJR3714) & & & & & & & \\
\hline & Solanum sp. & 35.2 & ++ & - & +++ & - & - & - \\
\hline & (FJR3173) & & & & & & & \\
\hline & Solanum & 0 & ++ & - & - & + & + & - \\
\hline & stellatiglandulosum & & & & & & & \\
\hline & Bitter (FJR3744) & & & & & & & \\
\hline & Solanum sycophanta & 0 & - & + & + & + & - & - \\
\hline & Dunal (FJR3737) & & & & & & & \\
\hline & Witheringia & 10.6 & + & - & - & - & - & - \\
\hline & coccoloboides & & & & & & & \\
\hline & (Damn.) Hunz. & & & & & & & \\
\hline & (FJR3155) & & & & & & & \\
\hline \multicolumn{2}{|c|}{ Hydroquinone $(100 \mathrm{mg} / \mathrm{L})$} & 35.77 & & 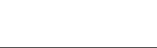 & & & & \\
\hline
\end{tabular}

\section{RESULTS AND DISCUSSION}

In this study the effect on the free radical scavenging ability was determined trough the DPPH assay because it is one of the most effective, reactive, reliable, simple and reproducible in vitro method for evaluating this important activity of single compounds as well as plant extracts (Kŏleva et al., 2002; Katalinic et al., 2006; Vicentino and Menezes, 2007; Balestrin et al., 2008).

The percentages of antioxidant activity are shown in Table I. Only seventeen (37\%) methanol extracts studied displayed a percentage of antioxidant activity equal or higher than $25 \%$, which was considered significant, based on the facts that methanol extracts are complex matrices. The most effective families studied for their antioxidant activity were the Euphorbiaceae with 7 active out of 9 methanol extracts analyzed, followed by the Melastomataceae with 3 out of 5 and the Solanaceae family with 3 out of 17 , among others.

The highest antioxidant activity among the analyzed plant extracts were shown by Phyllanthus sp. (54.0\%, Euphorbiaceae), followed by the two species included in the Melastomataceae family Tibouchina grossa (47.0\%) and Miconia lehmannii Cogn. (45.3\%), and Lycianthes radiata ( $41.4 \%$, Solanaceae). This is the first report on the antioxidant activity of these species.

It should be noted that compared to the positive control, the antioxidant activity of Phyllanthus sp. was 1.5 times stronger than hydroquinone, this result is in agreement with those of Phyllanthus debilis that showed the strongest antioxidant activity among five Phyllanthus species studied (Kumaran and
Karunakaran 2006). In this work Phyllanthus niruri L. (Euphorbiaceae) showed a weak antioxidant activity attributed to the presence of tannins and flavonoides. On the contrary, $P$. niruri showed good in vitro as well as in vivo antioxidant activity and it is considered a powerful oxygen radical scavenger, attributed to the presence of flavonoids, polyphenols, tannins, and lignans (Harish and Shivanandappa, 2006). Furthermore, Phyllanthus emblica L. has strong antioxidant activity attributed to hydrolysable tannins (Scartezzini and Speroni, 2000) and Acalypha indica L. (Euphorbiaceae) exhibited $81.6 \%$ of antioxidant activity evaluated through the DPPH assay (Marwah et al., 2007).

In this study, the results of the antioxidant activity on the species belonging to the Melastomataceae family correlate with previous studies with species belonging to others genera of this family; for instance, from Mouriri pusa has been isolated several flavonoids and tannins to which are attributed the antioxidant activity of this species (Andreo et al., 2006).

In this work Mikania leiostachya showed weak free radical (DPPH) scavenging activity. However, in a screening from natural plant resources from Brazil showed that Mikania psilostachya (Asteraceae), belonging to the same genuns Mikania, displayed strong free radical $(\mathrm{DPPH})$ scavenging activity $(\mathrm{IC} 50=8.3$ ) (Parejo et al., 2003).

The high antioxidant activity percentages of the methanol extracts from Phyllanthus sp., T. grossa and M. lehmannii Cogn. could be attributed to the presence of tannins; while in L. radiata extract could be owed to its flavonoid constituents, as was evidenced by the phytochemical screening, see Table I. These results are in agreement with the statement of Opoku et al., 
(2002), Mahakunakorn et al., (2004), and Katalinic et al., (2006), in the way that many phenolic compounds, widely distributed in the plant kingdom, behave as reducing agents with antioxidant and free radicalscavenging activities.

Flavonoids commonly occur as glycosides in plants. Phenols and polyphenols exert their protective effects through diverse mechanism such as blocking, interfering or suppressing the activities of enzymes involved in reactive oxygen species generation, quenching free radicals, chelating transition metals to render inactive species (Wong et al., 2006).

In conclusion, the free radical-scavenging activities for 46 plant extracts were evaluated by using the 1,1-diphenyl-2-picrylhydrazyl (DPPH) method, providing to be effective for the selection of four species with strong antioxidant activities with potential use in food, cosmetics and medicinal preparations. Further studies on the Phyllanthus sp, T. grossa, M. lehmannii and $L$. radiata methanolic extracts are required to isolate and identify the secondary metabolites responsible for their antioxidant activity.

\section{ACKNOWLEDGEMENTS}

The authors would like to thank The Universidad Tecnológica de Pereira for the financial support given to the project and to The Corporación Autonoma Regional de Risaralda (CARDER) for granting the permission to access plant collection.

\section{REFERENCES}

Andreo MA, Rodríguez KVB, Hiruma-Lima CA, Da Rocha LRM, Souza Brito ARM, Vilegas W 2006. Effect of Mouriri pusa extracts on experimentally induced gastric lesions in rodents: role of endogenous sulfhydryls compounds and nitric oxide in gastroprotection. J. Ethnopharmacol 107: 431- 441.

Balestrin L, Dias JFG, Miguel OG, Dall'Stella DSG, Miguel MD 2008. Contribuição ao estudo fitoquímico de Dorstenia multiformis Miquel (Moraceae) com abordagem em atividade antioxidante. Rev Bras Farmacogn 18: 230-235.

Brand-Williams W, Cuvelier M, Berset C 1995. Use of a free radical method to evaluate antioxidant activity. Lebensm-Wiss Technol 28: 25-30.

Cardoso CL, Silva DHS, Castro-Gamboa I, Bolzani VS 2005. New biflavonoid and other flavonoids from the leaves of Chimarrhis turbinata and their antioxidant activities. J Braz Chem Soc 16: 1353-1359.

David JP, Meira M, David JM, Brandão N, Branco A, Agra MF, Barbosa MRV, De Quiroz LP, Giulietti AM 2007. Radical scavenging, antioxidant and cytotoxic activity of Brazilian Caatinga plants. Fitoterapia 78 : 215-218.

Galeano MP, Bernal RG 1993. Guía de las plantas del Parque Regional Natural Ucumari. Tomo I. CARDER. Pereira: Editorial Graficas Buda Ltda.

Golden TR, Hinerfeld DA, Melov S 2002. Oxidative stress and aging: beyond correlation. Aging Cell 1: 117-123.

Gonçalves C, Dinis T, Batista MT 2005. Antioxidant properties of proanthocyanidins of Uncaria tomentosa bark decoction: a mechanism for anti-inflammatory activity. Phytochemistry 66: 89-98.

Harborne JB 1980. Phytochemical methods: a guide to modern techniques of plant analysis. London: Chapman and Hall.

Harish R, Shivanandappa T 2006. Antioxidant activity and hepatoprotective potential of Phyllanthus niruri. Food Chem 95: 180 -185.

Katalinic V, Milos M, Kulisic T, Jukic M 2006. Screening of 70 medicinal plant extracts for antioxidant capacity and total phenols. Food Chem 94: 550-557.

Kim HW, Murakami A, Williams MV, Ohigashi H 2003. Mutagenicity of reactive oxygen and nitrogen species as detected by co-culture of activated inflammatory leukocytes and AS52 cells. Carcinogenesis 24: 235241.

Kŏleva II, Van Beek TA, Linssen JPH, De Groot A, Evstatieva LN 2002. Screening of plant extracts for antioxidant activity: a comparative study on three testing methods. Phytochem Anal 13: 8-17.

Kumaran A, Karunakaran RJ 2006. Antioxidant and free radical scavenging activity of an aqueous extract of Coleus aromaticus. Food Chem 97: 109-114.

Lim YY, Murtijaya J 2007. Antioxidant properties of Phyllanthus amarus extracts as affected by different drying methods. LWT-Food Sci Technol 40: $1664-$ 1669.

Mahakunakorn P, Tohda M, Murakami Y, Matsumoto K, Wanatabe H 2004. Antioxidant and free radicalscavenging activity of choto-san and its related constituents. Biol Pharm Bull 27: 38-46.

Marwah RG, Fatope MO, Al Mahrooqi RS, Varma GB, Al Abadi H, Al-Burtamani KS 2007. Antioxidant capacity of some edible and wound healing plants in Oman. Food Chem 101: 465-470.

Niño J, Correa YM, Mosquera OM 2006. Antibacterial, antifungal, and cytotoxic activities of 11 Solanaceae plants from Colombian biodiversity. Pharm Biol 44: 14-18.

Parejo I, Viladomat F, Bastida J, Rosas-Ramo A, Saavedra G, Murcia MA, Jiménez AM, Codina C 2005. Investigation of Bolivian plant extracts for their radical scavenging activity and antioxidant activity. Life Sci 73: 1667-1881.

Pelicano H, Carney D, Huang P 2004. ROS stress in cancer cells and therapeutic implications. Drug Resist Update 7: 97-110.

Opoku AR, Masek, NF, Terblanche SE 2002. The in vitro antioxidative activity of some traditional Zulu medicinal plants. Phytother Res 16: 51-56.

Ribeiro AB, Bolzani VS, Yoshida M, Santos LS, Eberlin MN, Silva DHS 2005. A new neolignan and antioxidant phenols from Nectandra grandiflora. J Braz Chem Soc 16: 526-530.

Scartezzini P, Speroni E 2000. Review on some plants of Indian traditional medicine with antioxidant activity. J Ethnopharmacol 71: 23-43.

Tapia A, Rodriguez J, Theoduloz C, Lopez S, Feresin GE, Schmeda-Hischmann G 2004. Free radical scavengers and antioxidants from Baccharis grisebachii. $J$ Ethnopharmacol 95: 155-161.

Van Houten B, Woshner V, Santos JH 2006. Role of mitochondrial DNA in toxic responses to oxidative stress. DNA Repair 5: 145-152.

Vicentino ARR, Menezes FS 2007. Atividade antioxidante de tinturas vegetais, vendidas em farmácias com manipulação e indicadas para diversos tipos de doenças pela metodologia do DPPH. Rev Bras Farmacogn 17: 384-387.

Wong SP, Leong LP, Koh JHW 2006. Antioxidant activities of aqueous extracts of selected plants. Food Chem 99: $775-783$. 